\title{
New-onset Atrial Fibrillation: An Independent Predictor of in-hospital Mortality in Reduced Ejection Fraction Heart Failure Patients
}

\author{
Düşük Ejeksiyon Fraksiyonlu Kalp Yetersizliği Hastalarında Hastane Içi Mortaliteyi Artıran \\ Bağımsız Bir Belirteç Olarak Yeni Başlangıçlı Atriyal Fibrilasyon
}

\author{
๑i Nil Özyüncü, (1) Sadi Güleç \\ Ankara University School of Medicine, Department of Cardiology, Ankara, Turkey
}

\section{Abstract}

Objectives: Heart failure (HF) is associated with high mortality and atrial fibrillation (AF) is the most common arrhythmia encountered in HF patients with reduced ejection fraction (EF). We aimed to assess whether new-onset AF is an independent poor prognostic factor in this group of patients. We also searched for parameters that might influence the in-hospital mortality in reduced EF heart failure (HFrEF) patients.

Materials and Methods: The study was a retrospective observational study investigating the admission characteristics and in-hospital events for 119 HFrEF patients at sinus rhytym, admitted for decompensated heart failure. We evaluated the in-hospital mortality and aimed to identify the predictive factors.

Results: Overall $12 \%$ of the heart failure patients died during hospitalization. The mean age of the study population was $71 \pm 9$ years with $37 \%$ female. The mean EF was $27 \pm 7 \%$ and mean duration of hospitalization was $9 \pm 4$ days. Patients with lower body mass index, lower glomerular filtration rate and patients with longer hospitalization had significantly higher in-hospital mortality rates $(p=0.02, p=0.04$ and $p=0.001$, respectively). New-onset $A F$, restrictive filling pattern and being angiotensin-converting enzyme inhibitors/angiotensin receptor blockers naive were factors significantly related to higher mortality $(p=0.001, p=0.001$ and $p=0.02$, respectively). Long hospitalization duration and new-onset $A F$ at hospital were independent predictors of in-hospital mortality [ $p=0.006$ Odds ratio (OR): 1.394 (1.098-1.771) and $p=0.012$ OR: 10.869 (2.677-71.428), respectively].

Conclusion: In hospital outcome of patients admitted with decompensated HFrEF is poor. In our trial, patients with new-onset AF and patients with longer hospitalization duration had higher mortality rates. An understanding of the risk factors for in-hospital deaths may help improving intensive care for this patient population.

Key Words: New Onset Atrial Fibrillation, Heart Failure Reduced Ejection Fraction, Mortality

\section{Öz}

Amaç: Kalp yetersizliği yüksek mortalite ile ilişkili olup, atriyal fibrilasyon (AF) düşük ejeksiyon fraksiyonlu kalp yetersizliği (HFrEF) hastalarında en sık görülen aritmidir. Çalışmamızda, bu hastalarda yeni başlangıçlı AF'nin bağımsız prognostik bir belirteç olup olmadığını araştırdık. Ayrıca, çalışmamızda HFrEF hastalarında hastane içi mortaliteyi etkileyen diğer parametreler de değerlendirildi.

Gereç ve Yöntem: Çalışmamız retrospektif, gözlemsel bir çalışmadır. Dekompanse kalp yetersizliği nedeniyle hastanemize kabul edilen sinüs ritmindeki 119 düşük ejeksiyon fraksiyonlu (EF) hasta yatış özellikleri, hastane içi olaylar ve mortalite açısından değerlendirilmiştir.

Bulgular: Hastaların \%12'si hastane izlemi sırasında kaybedilmiştir. Hastaların ortalama yaşı 71 \pm 9 olup \%37'si kadındır. Ortalama EF'si $27 \pm 7$ olup ortalama hastanede yatış süresi $9 \pm 4$ gündü. Düşük vücut kitle indeksi, düşük glomerüler filtrasyon hızı ve uzun hastane yatışı olan hastalar daha fazla hastane içi mortaliteye sahipti (sırasıyla; $p=0,02, p=0,04$ ve $p=0,001$ ). Yeni başlangıçlı $A F$, restriktif doluş bozukluğu ve anjiyotensin enzim/ reseptör inhibitörleri kullanmamak da yüksek hastane içi mortalite ile anlamlı olarak ilişkiliydi (sırasıyla; $p=0,001, p=0,001$ ve $p=0,02$ ). Uzun hastane yatışı ve yeni başlangıçlı AF hastane içi mortalite için bağımsız belirleyiciler olarak saptandı [sırasıyla $p=0,006$ Odds oranı (0R): 1,394 (1,0988-1,771] ve $p=0,012$ OR: 10,869 (2,677-71,428)].

Sonuç: Hastaneye dekompanse olarak kabul edilen HFrEF hastalarında prognoz kötüdür. Çalışmamızda yeni başlangıçlı AF ve uzamış hastane yatışının mortalite üzerine bağımsız olarak etki eden belirteçler olduğunu saptadık. Hastane içi ölümlere etki eden prognostik belirteçleri iyi saptayabilmek, bu hastalarda daha yoğun ve etkin hedefler için yardımcı olabilir.

Anahtar Kelimeler: Yeni Başlangıçı Atriyal Fibrilasyon, Düşük Ejeksiyon Fraksiyonlu Kalp Yetersizliği, Mortalite

Address for Correspondence/Yazışma Adresi: Spc. Dr. Nil Özyüncü, MD,

Ankara University School of Medicine, Department of Cardiology, Ankara, Turkey

Phone: +90 3125082523 E-mail: nilozyuncu@yahoo.com ORCID ID: orcid.org/0000-0002-1845-5287

Received/Geliş Tarihi: 17.04.2020 Accepted/Kabul Tarihi: 13.05.2020

๑Copyright 2020 Ankara University Faculty of Medicine

Journal of Ankara University Faculty of Medicine is published by Galenos Publishing House.

All content are under CC BY-NC-ND license. 


\section{Introduction}

Heart failure (HF) is increasing in prevalence all over the world. Its most common form, reduced ejection fraction (EF) HF (HFrEF), is associated with significant mortality and morbidity due to pump dysfunction and arrhythmias. Atrial fibrillation (AF) is the most common associated arrhythmia, and it shows an increased incidence in $\mathrm{HF}$ compared with non-HF patients (1). AF has its mortality and morbidity burden, but it also accelerates the progression of $\mathrm{HF}$ and has an extra negative contribution to the ongoing disease state. New-onset AF was shown to double the annualized crude mortality rates in patients with advanced HF (2). However, there is no consistency in the literature about the unfavorable prognostic effect of AF in patients with HFrEF because of the need to adjust variables associated with worse outcomes. As a result, controversy remains about whether AF is an independent prognostic factor in this patient group $(3,4)$.

Patients with HF experience nearly 1,100,000 hospitalizations yearly, and in-hospital mortality is still an understudied component of adverse HF outcomes (5). We aimed to investigate whether new-onset AF is a poor prognostic factor for in-hospital mortality. In addition, we evaluated the clinical and laboratory parameters for their potential effects on in-hospital mortality.

\section{Material and Methods}

Patients hospitalized for acute decompensated $\mathrm{HF}$ at Ankara University Shool of Medicine, Department of Cardiology from January 2017 to June 2018, were evaluated retrospectively. Patients both with dilated and ischemic cardiomyopathy were included in our study. Exclusion criteria were: 1) left ventricular EF $>40 \%$, 2) acute coronary syndrome, 3) hemodynamic instability like cardiogenic or septic shock and patients who needed cardiopulmonary resuscitation, 4) newly diagnosed $\mathrm{HF}$ (diagnosis $<3$ months), 5) patients with known $\mathrm{AF}$ or $\mathrm{AF}$ at admission, 6) end-stage renal failure [glomerular filtration rate $(G F R)]<15 \mathrm{~mL} / \mathrm{min} / 1.73 \mathrm{~m}^{2}$ ) or dialysis patients, and 7) patients with signs of active infection or sepsis.

The local ethics committee approved the study protocol (date: 10.10.2016, decision no: 15-756-16).

Patients' admission vital functions, laboratory data and echocardiographic parameters were noted to charts routinely, as well as their daily clinical progression and mortality reports if death occured. Admission laboratory values were used for statistical comparison. EF was measured by transthoracic echocardiography at admission and the modified Simpson method was used. Restrictive filling at echocardiography was determined according to the diastolic mitral inflow velocity patterns. The term, new-onset $A F$, included patients having $\mathrm{AF}$ during hospitalization and was diagnosed by 12 lead electrocardiography with at least 30 seconds of an AF rhythm trace. AF management and treatment were done according to the recent guidelines (6). The decompensated state was diagnosed according to the modified Framingham Criteria (7). Patients were managed according to the recent HF management guideline of the European Society of Cardiology (8). Patient characteristics and in-hospital data were compared between the two groups, patients with and without in-hospital mortality.

\section{Statistical Analysis}

Statistical analyses were performed using the SPSS software package (version 20 for Windows, SPSS Inc., Chicago, Illinois). Discrete variables were expressed as numbers and percentages, whereas continuous variables were expressed as means \pm standard deviations. A chi-square analysis or Fisher's exact test was used for the categorical variables, and the Student's t-test or Mann-Whitney U test was performed for the continuous variables. A multivariable logistic regression analysis was performed to assess the independent predictors of in-hospital mortality. Gender, age, and variables with a $p<0.1$ in the univariate analysis were subjected to multivariate analysis. A probability value of $p<0.05$ was considered significant.

\section{Results}

One hundred and nineteen patients with normal sinus rhythm and $\mathrm{HFrEF}$, hospitalized for decompensation were evaluated in our trial. The mean age of the study population was $71 \pm 9$ years, with $37 \%$ of the female gender. The mean EF was $27 \pm 7 \%$ and the mean duration of hospitalisation was $9 \pm 4$ days. Overall, $12 \%$ $(n=14)$ of patients died during hospitalization. The main reasons for death were pulmonary edema (50\%) and cardiogenic shock (29\%). Other reasons were sepsis (14\%) and lethal arrhythmic death (ventricular tachycardia/fibrillation) (7\%). New-onset AF occured in 14 patients (11\%) during the hospitalization. Electrical or medical cardioversion was performed in eight patients; two patients recovered to sinus rhythm medically by amiodarone, the others required electrical cardioversion (one was unsuccessful, and two relapsed during hospitalization). The remaining six patients were followed up with heart rate control. Drugs for rate control were mainly beta-blockers and digitalis if treatment with beta-blockers was not tolerated or not enough. The decision was made by the attending physician according to the clinical guidelines and patient status. A prophylactic low molecular weight heparin anticoagulant regimen was routinely applied in patients with decompensated HF, the dose was increased to therapeutic levels for patients with new onset-AF (7). During the hospitalization period, no patients had a stroke, hemorrhagic-complications, or digitalis toxicity as AF morbidity.

Baseline characteristics of patients according to in-hospital mortality, are given in Table 1. Patients with a ower body mass 
index (BMI), lower GFR, and patients with longer hospitalization duration had significantly higher in-hospital mortality rates ( $p=0.02, p=0.04$ and $p=0.001$, respectively). New-onset AF at hospital, restrictive filling pattern on echocardiography and

\begin{tabular}{|c|c|c|c|}
\hline & $\begin{array}{l}\text { In hospital } \\
\text { mortality } \\
(+)(n=14)\end{array}$ & $\begin{array}{l}\text { In hospital } \\
\text { mortality }(-) \\
(n=105)\end{array}$ & $\begin{array}{l}p \\
\text { value }\end{array}$ \\
\hline Age, year mean \pm SD & $74 \pm 8$ & $71 \pm 9$ & 0.32 \\
\hline Women, n (\%) & $5(36 \%)$ & $39(37 \%)$ & 0.91 \\
\hline Body mass index $\left(\mathrm{kg} / \mathrm{m}^{2}\right)$ & $25 \pm 6$ & $29 \pm 4$ & 0.02 \\
\hline Hypertension, n (\%) & $7(50 \%)$ & $7(50 \%)$ & 0.52 \\
\hline Diabetes Mellitus, n (\%) & $8(57 \%)$ & $68(65 \%)$ & 0.57 \\
\hline Current smokers, n (\%) & $4(29 \%)$ & $19(18 \%)$ & 0.35 \\
\hline WBC at admission $\left(10^{9} / \mathrm{L}\right)$ & $9.1 \pm 3.3$ & $8.7 \pm 3.6$ & 0.75 \\
\hline C-reactive protein, (mg/L) & $30.5 \pm 37.4$ & $22.9 \pm 24.6$ & 0.31 \\
\hline $\begin{array}{l}\text { Brain natriuretic peptide, } \\
(\mathrm{pg} / \mathrm{mL})\end{array}$ & $1756 \pm 991$ & $1429 \pm 890$ & 0.22 \\
\hline GFR $\left(\mathrm{mL} / \mathrm{min} / 1.73 \mathrm{~m}^{2}\right)$ & $40 \pm 18$ & $51 \pm 19$ & 0.04 \\
\hline $\begin{array}{l}\text { Oxygen saturation (\%) by } \\
\text { probe }\end{array}$ & $88 \pm 5$ & $86 \pm 5$ & 0.26 \\
\hline $\begin{array}{l}\text { Systolic blood pressure on } \\
\text { admission }(\mathrm{mmHg})\end{array}$ & $96 \pm 28$ & $110 \pm 26$ & 0.10 \\
\hline $\begin{array}{l}\text { New onset atrial fibrillation } \\
\text { during hospitalization, } \mathrm{n}(\%)\end{array}$ & $6(43 \%)$ & $8(8 \%)$ & $<0.001$ \\
\hline NYHA class 4, n (\%) & $8(\% 57)$ & $49(\% 46)$ & 0.69 \\
\hline $\begin{array}{l}\text { Dilated cardiomyopathy, } \mathrm{n} \\
(\%)\end{array}$ & $2(14 \%)$ & $17(16 \%)$ & 0.85 \\
\hline $\begin{array}{l}\text { Inotropic support during } \\
\text { hospitalization, } \mathrm{n}(\%)\end{array}$ & $4(29 \%)$ & $16(15 \%)$ & 0.21 \\
\hline Patients with ICD, n (\%) & $2(27 \%)$ & $14(13 \%)$ & 0.35 \\
\hline $\begin{array}{l}\text { Hospitalization duration } \\
\text { (day) }\end{array}$ & $12 \pm 6$ & $8 \pm 4$ & $<0.001$ \\
\hline \multicolumn{4}{|c|}{ Medications used on admission } \\
\hline Statin, n (\%) & $7(50 \%)$ & $61(58 \%)$ & 0.56 \\
\hline $\begin{array}{l}\text { Angiotensin-converting } \\
\text { enzyme inhibitors/ } \\
\text { Angiotensin receptor } \\
\text { blockers, n (\%) }\end{array}$ & $6(43 \%)$ & $77(73 \%)$ & 0.02 \\
\hline Beta blocker, n (\%) & $8(57 \%)$ & 79 (75\%) & 0.15 \\
\hline Ivabradine, n (\%) & $3(21 \%)$ & $19(18 \%)$ & 0.69 \\
\hline \multicolumn{4}{|c|}{ Echocardiographic parameters } \\
\hline $\begin{array}{l}\text { Restrictive pattern of filling, } \\
n(\%)\end{array}$ & $9(64 \%)$ & $24(23 \%)$ & $<0.001$ \\
\hline Ejection fraction $(\%)$ & $25 \pm 7$ & $28 \pm 8$ & 0.18 \\
\hline $\begin{array}{l}\text { Pulmonary artery systolic } \\
\text { pressure, } \mathrm{mmHg}\end{array}$ & $51 \pm 8$ & $46 \pm 13$ & 0.51 \\
\hline
\end{tabular}

being angiotensin-converting enzyme inhibitor/ angiotensin receptor blocker (ACE-I/ARB) drugs naive were factors significantly related to higher in-hospital mortality $(p=0.001$, $p=0.001$ and $p=0.02$, respectively). In logistic regression analysis, long hospitalization duration and new-onset AF at hospital were independent predictors of in-hospital mortality $[p=0.006$ Odds ratio (OR): 1.394 (1.0988-1.771) and $p=0.012$ OR: 10.869 (2.677-71.428), respectively] (Table 2).

\begin{tabular}{lll}
$\begin{array}{l}\text { Table 2: Predictors of in hospital mortality by multivariate } \\
\text { logistic regression analysis }\end{array}$ & p value \\
\hline & OR (95\%, Cl) & 0.446 \\
\hline Age & $1.032(0.951-1.121)$ & 0.718 \\
\hline Male gender & $1.335(0.278-6.414)$ & 0.279 \\
\hline BMI & $0.924(0.801-1.066)$ & 0.012 \\
\hline Atrial fibrillation at hospital & $10.869(2.677-71.428)$ & 0.691 \\
\hline Glomerular filtration rate & $1.008(0.968-1.050)$ & 0.191 \\
\hline ACE/ARB use & $0.361(0.078-1.658)$ & 0.006 \\
\hline Hospitalization duration & $1.394(1.098-1.771)$ & 0.172 \\
\hline Restrictive filling pattern & $2.941(0.624-13.888)$ & \\
\hline
\end{tabular}

ACE/ARB: Angiotensin-converting enzyme inhibitors/Angiotensin receptor blockers BMI: Body mass index, $\mathrm{Cl}$ : Confidence interval, OR: Odds ratio

\section{Discussion}

In this cohort of 119 patients hospitalized for decompensation with $\mathrm{HFrEF}$, the rate of in-hospital mortality was $12 \%$. Newonset AF during hospitalization and longer hospitalization duration were the two independent factors negatively affecting the in-hospital mortality. To the best of our knowledge, this is the first study of an association between new-onset AF and inhospital mortality of HFrEF patients.

$\mathrm{AF}$ is the most common arrhythmia in patients with $\mathrm{HFrEF}$, and its presence increases the severity of HF. The prevalence of AF reaches up to $50 \%$ in patients with New York Heart Association functional class IV (9). In some studies, AF was shown to cause a poorer prognosis. However, results were not consistent after adjusting for other variables associated with worse outcomes. Mogensen et al. (10), analyzed 15,415 patients enrolled in two large trials (PARADIGM-HF and ATMOSPHERE) and evaluated the type of AF affecting the outcome of patients with HFrEF. Newonset AF was associated with the greatest risk of adverse events. In a trial that tested the hypothesis whether new-onset AF was related to HF progression, there was a 2-fold increase in mortality and a 4.5-fold increase in hospitalization burden in new-onset AF patients, at the 2-year follow up (2). This risk attributed to newonset AF can be partially explained by established chronic AF in the setting of HF represents a selected survivor patient group. However, new-onset AF allows the detection of the adverse events prospectively (11). Multicenter Automatic Defibrillator Implantation Trial (MADIT-II), had also concluded the 2-fold 
increase in mortality in HF patients with new-onset AF (12). The analysis of ACALM (Algorithm of Comorbidities, Associations, Length of stay and Mortality) registry, a comprehensive longterm registry of 1,000,000 patients, the coexistence of AF and $\mathrm{HF}$ was found to have the greatest all-cause mortality rate and longer hospital stay (13). In our trial, we searched for the effect of parameters and characteristics of HFrEF patients on the rate of in-hospital mortality, not long-term mortality. Our results, like the literature, showed the negative impact of new-onset AF on the in-hospital mortality. This negative impact was not attributed to side effects of drugs used for $A F$, because there were no hemorrhagic complications during anticoagulation or drug toxicity during rate and rhythm control. However, AF is known to reduce the cardiac output further because of the loss of atrial contribution (7). This may be the key contributing factor to increased events and eventually increased mortality rates. Besides the new-onset $\mathrm{AF}$, longer hospitalization duration was also detected as an independent predictor. It could be predicted that patients with worse clinical progress and condition, would stay for longer times at the hospital, face to additional complications, and have higher mortality rates.

In a trial investigating the in-hospital mortality in acute decompensated HF patients, blood urea nitrogen level on admission, serum creatinine level, and low admission systolic blood pressure were found to be the best mortality predictors. A risk tree made according to parameters of 65,275 patients revealed in-hospital mortality ranging from $2.1 \%$ to $21.9 \%$ (14). This trial included HF patients with both reduced and preserved EF. It is known that important differences exist between these two groups of patients regarding clinical characteristics and inhospital mortality (5). In our trial of patients with HFrEF and sinus rhythm on admission, we found that a lower BMI, lower GFR, longer hospitalization duration, new-onset AF in the hospital and the restrictive filling pattern on echocardiography were factors that significantly increased in-hospital mortality. Being on ACE-I/ARB drugs before admission was protective against inhospital mortality. These factors were all in accordance with the literature; however, one cannot conclude a definite association because of the small number of patients enrolled in our trial (15-17). We believe the independent association of in-hospital mortality and new-onset AF should be considered since it was detected in a very select patient population. Of course, the data needs to be further verified with larger randomized studies.

\section{Study Limitations}

A major limitation of our study is that it is a retrospective analysis with a small number of patients from a single center. Our results represent the data of hospital follow-up 119 patients who were selectively enrolled and admitted with decompensation of HFrEF. We believe that we included valuable data for further research; however, our results and conclusions should be interpreted with caution.

\section{Conclusion}

Our data suggest that patients with new-onset AF and those with longer hospitalization durations had higher in-hospital mortality rates. We believe that this data should reinforce the value of optimal HF treatment according to guidelines, not only to slow disease progression but also to reduce the risk of new-onset AF. New-onset AF in a HFrEF patient should alert the physician to the need of heightened clinical observation and to consider more intensified HF treatment.

\section{Ethics}

Ethics Committee Approval: This study was approved by Ankara University School of Medicine, Clinical Researches Ethics Committee (date: 10.10.2016, decision no: 15-756-16).

Informed Consent: Retrospective study.

Peer-review: Externally peer-reviewed.

\section{Authorship Contributions}

Surgical and Medical Practices: N.Ö., Concept: N.Ö., S.G., Design: N.Ö., S.G., Data Collection or Processing: N.Ö., Analysis or Interpretation: N.Ö., S.G., Literature Search: N.Ö., Writing: N.Ö., S.G.

Conflict of Interest: No conflict of interest was declared by the authors.

Financial Disclosure: The authors declared that this study received no financial support.

\section{References}

1. Savelieva I, Camm AJ. Atrial fibrillation and heart failure: natural history and pharmacological treatment. Europace. 2004;5(Suppl 1):S5-S19.

2. Aleong RG, Sauer $W H$, Davis $G$, et al. New-onset atrial fibrillation predicts heart failure progression. Am J Med. 2014;127:963-971.

3. Benjamin EJ, Wolf PA, D'Agostino RB, et al. Impact of atrial fibrillation on the risk of death: the Framingham Heart Study. Circulation. 1998;98:946952.

4. Anter $E_{1}$ Jessup $M$, Callans DJ. Atrial fibrillation and heart failure: treatment considerations for a dual epidemic. Circulation. 2009;119:2516-2525.

5. Tribouilloy C, Rusinaru D, Leborgne L, et al. In-hospital mortality and prognostic factors in patients admitted for new-onset heart failure with preserved or reduced ejection fraction: a prospective observational study. Arch Cardiovasc Dis. 2008;101:226-234.

6. Kirchhof P, Benussi S, Kotecha D, et al. ESC Scientific Document Group. 2016 ESC Guidelines for the management of atrial fibrillation developed in collaboration with EACTS. Eur Heart J. 2016;37:2893-2962.

7. McKee PA, Castelli WP, McNamara PM, et al. The natural history of congestive heart failure: the Framingham study. N Engl J Med. 1971;285:1441-1446.

8. Ponikowski P, Voors AA, Anker SD, et al. Authors/Task Force Members; Document Reviewers. 2016 ESC Guidelines for the diagnosis and treatment of acute and chronic heart failure: The Task Force for the diagnosis and treatment of acute and chronic heart failure of the European Society of Cardiology (ESC). Developed with the special contribution of the Heart Failure Association (HFA) of the ESC. Eur J Heart Fail. 2016;18:891-975.

9. Ponikowski P, Voors AA, Anker SD, et al. ESC Scientific Document Group. 2016 ESC Guidelines for the diagnosis and treatment of acute and chronic 
heart failure: The Task Force for the diagnosis and treatment of acute and chronic heart failure of the European Society of Cardiology (ESC) Developed with the special contribution of the Heart Failure Association (HFA) of the ESC. Eur Heart J. 2016;37:2129-2200.

10. Mogensen UM, Jhund PS, Abraham WT, et al. PARADIGM-HF and ATMOSPHERE Investigators and Committees. Type of Atrial Fibrillation and Outcomes in Patients With Heart Failure and Reduced Ejection Fraction. J Am Coll Cardiol. 2017;70:2490-2500.

11. Pozzoli M, Cioffi G, Traversi E, et al. Predictors of primary atrial fibrillation and concomitant clinical and hemodynamic changes in patients with chronic heart failure: a prospective study in 344 patients with baseline sinus rhythm. J Am Coll Cardiol. 1998;32:197-204.

12. Zareba W, Steinberg JS, McNitt S, et al. MADIT II Investigators. Implantable cardioverter-defibrillator therapy and risk of congestive heart failure or death in MADIT II patients with atrial fibrillation. Heart Rhythm. 2006;3:631-637.
13. Ziff $0 J$, Carter PR, McGowan J, et al. The interplay between atrial fibrillation and heart failure on long-term mortality and length of stay: Insights from the, United Kingdom ACALM registry. Int J Cardiol. 2018;252:117-121.

14. Fonarow GC, Adams KF Jr, Abraham WT, et al. ADHERE Scientific Advisory Committee, Study Group, and Investigators. Risk stratification for inhospital mortality in acutely decompensated heart failure: classification and regression tree analysis. JAMA. 2005;293:572-580.

15. Bloom MW, Greenberg B, Jaarsma $T$, et al. Heart failure with reduced ejection fraction. Nat Rev Dis Primers. 2017;3:17058.

16. Bajraktari G, Miccoli M, Buralli $S$, et al. Plasma metalloproteinase-9 and restrictive filling pattern as major predictors of outcome in patients with ischemic cardiomyopathy. Eur J Intern Med. 2012;23:616-620.

17. Ruddox V, Sandven I, Munkhaugen J, et al. Atrial fibrillation and the risk for myocardial infarction, all-cause mortality and heart failure: A systematic review and meta-analysis. Eur J Prev Cardiol. 2017;24:1555-1566. 